\title{
Production of ingredients for cut cattle diet: a case study in farm angico, municipality of Corumbá - Mato Grosso do Sul
}

\author{
Diego Roberto Courbassier Pina ${ }^{1}$, Maurício Ferreira Lopes ${ }^{2}$, Tatiane Carla Silva ${ }^{3}$, Joane Alves Damasceno ${ }^{4}$ \\ Fabiano Borges de Vasconcellos ${ }^{2}$ \\ ${ }^{1}$ Fundação Getúlio Vargas - FGV,SP. ${ }^{2}$ Companhia Nacional de Abastecimento - Conab,Brasília, DF. ${ }^{3}$ Universidade Estadual \\ Paulista - UNESP, SP. ${ }^{4}$ Universidade Federal da Grande Dourados - UFGD, MS. E-mail: mauricio.lopes@conab.gov.br
}

\begin{abstract}
Nutrition has a fundamental role in the production of beef cattle, directly interfering in the costs, productivity and profitability of the activity. In this sense, the objective of the present study was to evaluate the challenges, opportunities and advantages of the production of the entire cattle fattening diet on the Angico farm, in the municipality of Corumbá - Mato Grosso do Sul. Applied research was carried out as a way of studying case. In the 2017/2018 harvest, the farm's own production yielded 116 bags/hectare of corn, 40 bags / hectare of soybeans, 42 tons / hectare of silage sorghum and 72.5 bags/hectare of grain sorghum. All these ingredients were used in the feed of the feedlot animals. It was concluded that at the Angico farm, with the use of proper planting and management techniques, it was possible to overcome production barriers (adverse weather, attack by pests, diseases and wild animals), thus improving the efficiency of the enterprise. In addition, it was possible to recover degraded pasture areas and increase the farm's food independence by reducing the purchase of food from third parties and reducing costs per arroba produced with the animals' own food production.
\end{abstract}

Keywords: large crops; animal nutrition; bovine feedlot; silage; maize and soy.

Produção de ingredientes para dieta de gado de corte: um estudo de caso na fazenda Angico, município de Corumbá - Mato Grosso do Sul

\section{Resumo}

A nutrição tem papel fundamental na produção de bovinos de corte, interferindo diretamente nos custos, produtividade e rentabilidade da atividade. Nesse sentido, o objetivo do presente estudo foi avaliar os desafios, oportunidades e vantagens da produção de toda a dieta de engorda de bovinos na fazenda Angico, município de Corumbá - Mato Grosso do Sul. Foi feita uma pesquisa aplicada, como forma de estudo de caso. A produção da própria fazenda rendeu na safra 2017/2018, 116 sacas/hectare de milho, 40 sacas/hectare de soja, 42 toneladas/hectare de sorgo silagem e 72,5 sacas/hectare de sorgo granífero. Todos estes ingredientes foram utilizados na ração dos animais do confinamento. Concluiu-se que na fazenda Angico, com o uso de técnicas de plantio e manejo adequadas, foi possível superar os entraves de produção (clima adverso, ataque de pragas, doenças e animais selvagens), melhorando, portanto, a eficiência do empreendimento. Além disso, foi possível recuperar áreas de pastagens degradadas e aumentar a independência alimentar da fazenda pela redução da compra de alimentos de terceiros e reduzir os custos por arroba produzida com a produção própria da alimentação dos animais.

Palavras-chave: grandes culturas; nutrição animal; confinamento bovino; silagem; milho e soja.

\section{Introduction}

Over the years, Brazilian livestock has been growing steadily (CARVALHO; ZEN, 2017).
Currently, with the advancement of studies, the bovine has gone from a simple breeding animal to large-scale production, directly contributing to 
exports and the Brazilian GDP, ensuring jobs throughout its production chain, generating profits and moving the economy with the production of food, whether meat, milk or slaughter by-products (SAMAIA, 2019)

Nutrition plays a fundamental role in the production of beef animals, directly interfering with the costs and productivity of the rearing system (BUSO et al., 2011). The importance of choosing the most adequate nutrition for each animal category is essential, as the more complete the diet, the shorter the time it will take for the animal to be slaughtered with the ideal weight, increasing the financial return for the producer. Thus, there is a constant search for diets that will offer maximum performance with reduced costs (SAMAIA; ANSELMO, 2019).

Beef cattle farming plays an important role in the world economic scenario. According to the Ministry of Agriculture, Livestock and Supply (MAPA), in 2017, 23.18 million heads of cattle were slaughtered in Brazil (BRASIL, 2020). Of this total, the state of Mato Grosso do Sul ranked second in the number of animals slaughtered with more than 3 million heads, equivalent to $13.62 \%$ of the national total (Table 1 ).

Table 1. Number of cattle slaughtered in the main Brazilian producing states in 2017.

\begin{tabular}{cc}
\hline States & Number of slaughtered heads \\
\hline MT & $4,349,665.0$ \\
MS & $3,157,112.0$ \\
GO & $2,821,914.0$ \\
SP & $2,406,077.0$ \\
RO & $2,267,046.0$ \\
PA & $2,174,194.0$ \\
\hline
\end{tabular}

Source: Brasil (2020)

According to projections for the beef production chain in Brazil, the sector is showing rapid and considerable growth, whose production growth is expected to be $1.9 \%$ per year, with a production forecast of 12.15 million tons in 2028, compared to a production of 9.90 million tons in 2018 (BRASIL, 2018). Regarding consumption, it is estimated that in 2028, the country will consume 9.28 million tons, compared to the consumption of 7.93 million tons in 2018 (BRASIL, 2018). For exports, the estimate is that in 2028, the country will export 2.75 million tons, compared to exports of 2.02 million tons in 2018 (BRASIL, 2018). According to the authors, among the countries that most import Brazilian beef are China, the United States, countries in Africa and the Middle East, Japan and South Korea.

The creation of cattle in a confinement system is commonly used in the country, where the animals are raised in a restricted area (paddocks), with a daily supply of balanced food and water (CARDOSO, 1996). This system is aimed at finishing animals, usually in times of drought, due to the low production and quality of pastures due to lack of water, a period in which if there is no confinement, the animals lose a lot of weight (SENAR, 2018). The producer chooses this breeding system seeking some advantages, such as increased herd production efficiency, greater standardization of carcass, reduction in the life cycle of the animal ready for slaughter, use of forage in the summer, among others (BRASIL, 2016).

The production of forage for confinement has always been a difficult and risky task, demanding high costs for the acquisition of machinery and high dependence on climatic factors for the production and storage of food. Feeding is responsible for approximately $70 \%$ of the total cost of confinement (CARDOSO, 2012). In this sense, producing the entire cattle diet on the property can be a sustainable and economically viable activity in any production system (BARIONE, et al., 2003). This choice between producing or buying food can have major impacts within a rural property. These impacts are due to the influence of costs and benefits that each alternative will bring.

To maintain competitiveness, the production of the entire bovine diet on the property must be constantly evaluated in a bovine production system, especially about economic aspects. In this sense, the objective of this study was to evaluate the challenges, 
opportunities and advantages of producing the entire diet for fattening cattle on the Angico farm, municipality of Corumbá - Mato Grosso do Sul.

\section{Material and Methods}

This study is classified as theoreticalempirical, because in addition to a conceptual discussion, a practical application was also sought. As for the type, it refers to applied research, with an inductive method and qualiquantitative nature.

Regarding the objectives, this research is classified as descriptive and primary source. According to Neuman (1997), descriptive research aims to describe processes, mechanisms and relationships existing in the reality of the phenomenon studied. Triviños (1987) states that "the descriptive study intends to accurately describe the facts and phenomena of a given reality".
As for the techniques, it is defined as documentary and bibliographic. In other words, it used materials that had not yet received an analytical treatment and a study developed from material already prepared, mainly books and scientific articles (GIL, 2008).

Among the various instruments available for data collection, the on-site observation of production and interviews with those involved in animal feeding were used in this study.

This study was carried out as case study research, using data provided by the Angico farm of the EMA Group (2019) (Empresa Marinho de Agropecuária do Pantanal Ltda) located on the margins of BR 262, Km 55 on the left side towards Corumbá - Campo Grande/ MS. The property is located at geographic coordinates $19^{\circ} 22^{\prime} 15^{\prime \prime} \mathrm{S}$ and $57^{\circ} 26^{\prime} 59^{\prime \prime} \mathrm{W}$ (Figure 1).

Figure 1. Aerial view of the Angico farm with detail of the headquarter and cattle confinement in the city of Corumbá - MS.

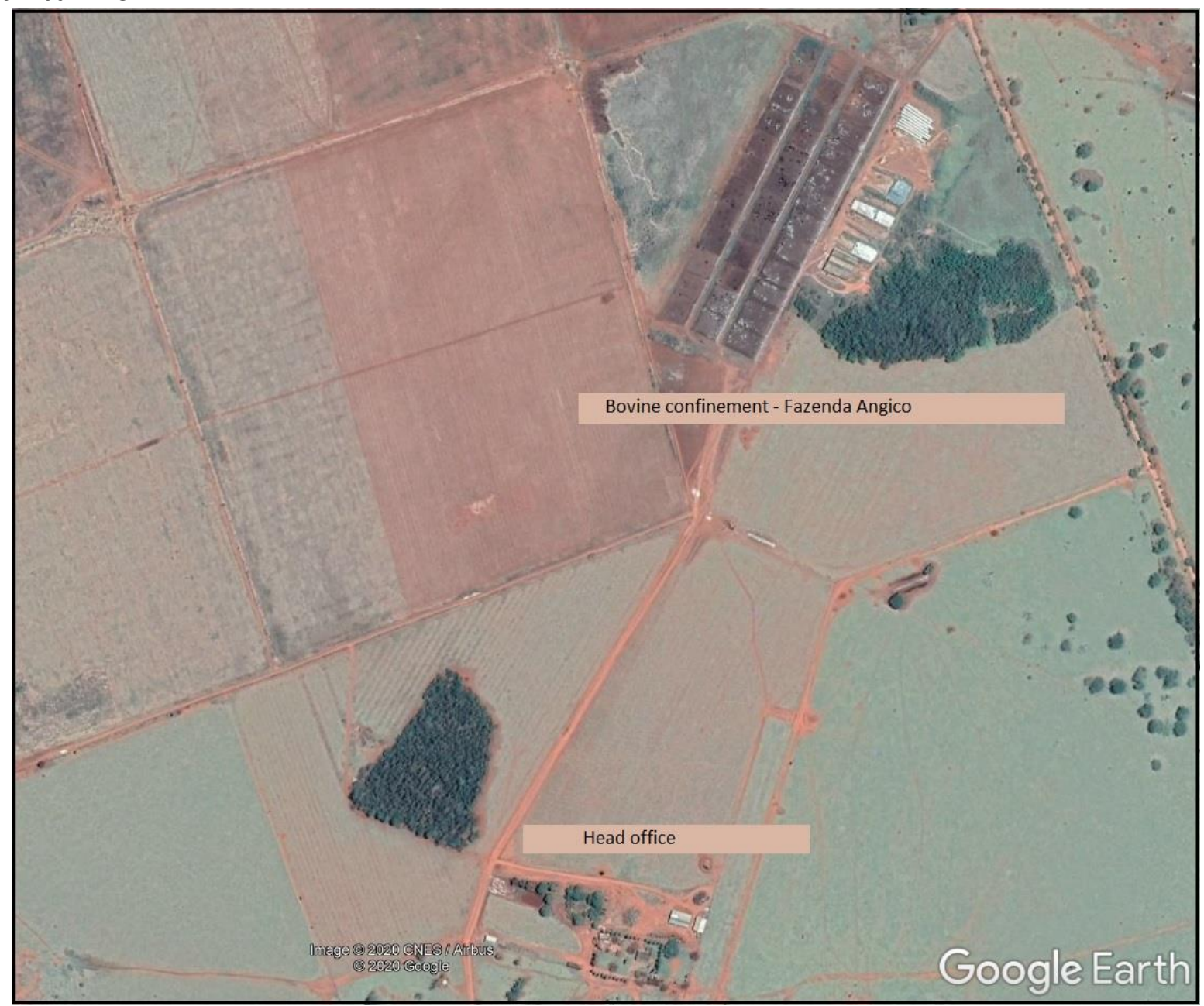


The farm has a total area of 4,503 hectares, of which 5 hectares are the headquarters, 1,583 hectares are for agriculture (soybean, sorghum and corn for animal feed), 1,800 hectares of pasture, 15 hectares for confinement and 1,100 hectares of legal reserve.
The entire property is divided into plots, as can be seen in figure 2 .

Figure 2. Floor plan of the Angico farm divided into plots in the municipality of Corumbá - MS.

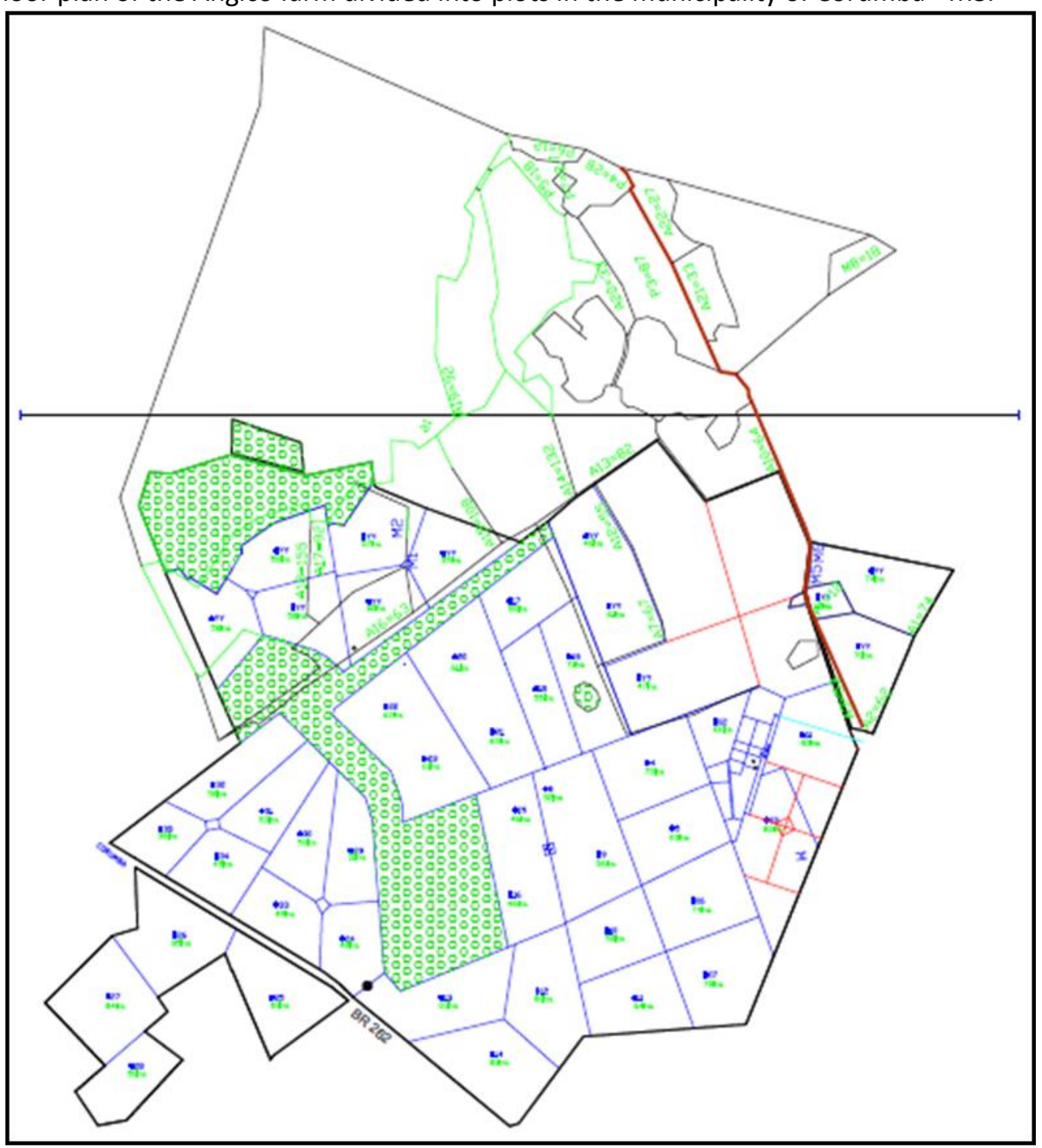

The farm's confinement consists of a $4,000 \mathrm{~m}^{2}$ shed for storing the feed ingredients, 06 trenchtype silos and a patio for the storage of a bagtype silo. The pens are distributed in 03 lines, each with 12 pens, holding up to 100 animals per pen (Figure 3). On average, per year, the turnover of animals is around 10,000 to 12,000 heads. 
Figure 3. Aerial view of the Angico farm with a detail of the bovine confinement in the city of Corumbá MS.

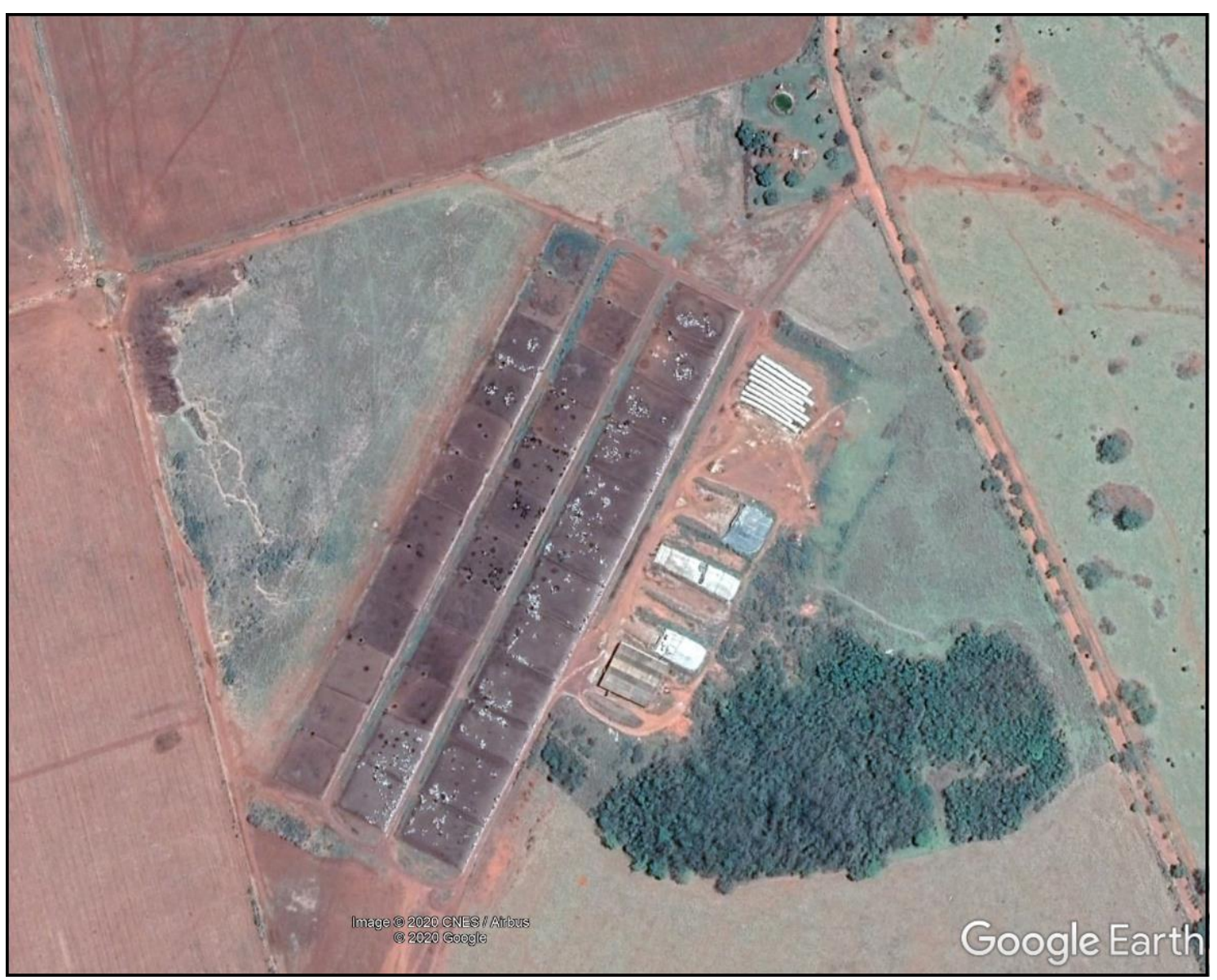

In the present work, only the second cycle of confinement of the years 2018/2019 was analyzed, between the months of July 2018 and March 2019, a period in which 5,810 animals were confined.

\section{Results and discussion}

The Angico farm serves as a pilot project for the Crop Livestock Integration system - ILP, with the recovery of degraded pasture areas, implementing agriculture intercropped with pasture, helping to dilute the costs of pasture reform by using grain production. During 2018 and 2019, 1,500 hectares of degraded pastures were recovered, which were destined to produce grains and roughage for animal feed.

In the confinement, a balanced diet was adopted, as shown in table (2), where $2.23 \%$ of the animal's live weight per day was provided, with the intention of a gain of $1.66 \mathrm{~kg} / \mathrm{head} /$ day, with daily feed cost more operational cost of $\mathrm{R} \$$ $6.36 /$ head/day, totaling a total cost of weight gain of approximately $\mathrm{R} \$ 78.00$ per arroba produced on the property. 
Table 2. Average total of feed consumed per animal during confinement and representation by ingredients in the confinement of Angico farm, municipality of Corumbá - MS, in 2018.

\begin{tabular}{ccc}
\hline Ingredients & Quantity (kg) & Representation (\%) \\
\hline Sorghum Silage & $2,664.0$ & $44.40 \%$ \\
Moist corn grain & $1,434.0$ & $23.90 \%$ \\
dry corn grain & $1,434.0$ & $23.90 \%$ \\
Soy & 360.0 & $6.00 \%$ \\
Core & 72.0 & $1.20 \%$ \\
Urea & 38.0 & $0.60 \%$ \\
\hline Total & $\mathbf{6 , 0 0 2 . 0 0}$ & $\mathbf{1 0 0 . 0 0 \%}$ \\
\hline
\end{tabular}

Among the main indicators of a confinement, the Average Daily Gain (ADG) deserves to be highlighted. It is a productivity index calculated with the following formula: $A D G=[$ (Current animal weight) - (Previous weight)] / (Days between the two weighings). The ADG shows how much weight in kilograms the animal gains per day (Table 3). This parameter is used to measure the performance of beef animals and assess the financial result of the production cycle (MELLO et al., 2009).

In the second cycle of Fazenda Angico, ADG ranged from 0.77 to $2.19 \mathrm{~kg} /$ day, but the average was $1.57 \mathrm{~kg} /$ day (Table 3). According to the work carried out by Peripolli et al. (2016), when studying economic values for rearing and fattening systems of Nellore and crossbred cattle, the ADG of the animals during the grazing period within the 24 months of the model was $0.450 \mathrm{~kg} /$ day and during confinement, the ADG was $1.3 \mathrm{~kg} /$ day. In a similar work, Mandarino et al. (2013), when evaluating the productive and economic performance of the confinement of Zebu cattle fed on high concentrate diets, observed ADG from 0.95 to 1.55 depending on the diet. In this context, it can be stated that the ADG of the Angico farm was above the average reported in the literature.

Table 3. Confinement indicators at Fazenda Angico, municipality of Corumbá - MS, in the second cycle of 2018/2019.

\begin{tabular}{lr}
\hline Number of animals (period from 07/23/2018 to 03/25/2019) & $5,810.00$ \\
Average feedlot entry weight $(\mathrm{kg})$ & 361.11 \\
Average feedlot output weight $(\mathrm{kg})$ & 505.56 \\
Average days of trough & 92.00 \\
ADG (Average Daily Gain) (kg/day) & 1.57 \\
Carcass yield (\%) & 0.56 \\
ADG standard deviation & 0.22 \\
\hline
\end{tabular}

For the present work, only the second cycle of confinement of the years 2018/2019 was analyzed, between the months of July 2018 and March 2019, when 5,810 animals were confined (Table 3). However, in 2018 and early 2019, approximately 11,000 animals were confined in the Angico farm.

With the production of food at the Angico Farm from 2018 onwards, there was an improvement in animal nutrition with a greater supply of food for the animals. Cattle started to eat a higher content of protein and energy, with an average consumption of approximately $1.8 \%$ of the live weight of dry matter and more than 20 kilos of silage.

Commodities are difficult to predict prices, because several factors contribute to the variability of quotations, such as internal and external supply and demand, exchange rates, agreements between countries, among other factors (CONAB, 2020). In 2018, Fazenda Angico paid a value of $R \$ 37.00$ to third parties for the $60 \mathrm{~kg}$ sack of corn grain, while the same product produced by the farm had a cost of $\mathrm{R} \$ 20.00$ per $60 \mathrm{~kg}$ sack. With the purchase of food from other properties, there was an increase in production costs, while in the $2017 / 2018$ production 
cycle, the average production cost of a confined at sign was approximately $\mathrm{R} \$ 76.00$ during the average 92 days of confinement.

In 2018, planting was adopted in challenging times (beginning of the rainy season in November), when normally there is no satisfactory rainfall, however, there is less attack by wild animals. The no-tillage system was adopted, where the straw is preserved to cover the soil, thus increasing the microbiotic life and providing a favorable soil microclimate. Less aggressive systems to the ecosystem (biological products) were implemented, using cultivars of corn, soybeans and sorghum with rustic characteristics and technologies resistant to pests and diseases.

The planted area of grain corn in the 2017/2018 harvest was 898 hectares, soybeans 80 hectares, sorghum silage 240 hectares, grain sorghum 120 hectares and off-season corn 245 hectares. The average yield of corn was 116 bags/hectare, soybeans 40 bags/hectare, sorghum silage 42 tons/hectare and grain sorghum 72.5 bags/hectare. Even with these productions, the Angico farm was unable to fatten the cattle it had for fattening in 2018/2019, and it was necessary to buy raw material, mainly corn from third parties. However, the dependence on external power was much less compared to previous confinement cycles.

When working with finishing cattle, attention must be paid to balance the diet and prevent metabolic disturbances. To have balance, it is necessary to mix additives (minerals), fibers (silage) and energy (corn). Energy is essential for the process of finishing beef animals, with corn being one of the most traditional foods to meet energy demands (CARDOSO, 2012). Soy participates as a protein source, the nucleus as micronutrients and urea as macronutrients (nitrogen source).

At Angico farm, a high-grain diet was also adopted (there is no forage supply, the animals are fed only with grain), which allows for greater individual weight gain, also standardizing the batch of animals. In addition, this diet allows for lower expenses, since there are no costs with silage production and storage. There are two factors that justify the adoption of this system: the price of production/acquisition of corn and the price of the bovine arroba to be sold (DIAS et al., 2016). The lower the price of corn and the higher the price of bovine arroba to be sold, the more advantageous is the adoption of a high-grain diet. With the bovine arroba in the average values of BRL 141.89 in the last six months of 2018 for the state of Mato Grosso do Sul (CONAB, 2019), and the cost of production of the sack of corn produced at the Angico farm of approximately BRL 20.00 that year, the adoption of this diet was viable.

\section{Conclusion}

With the production of food in the Angico farm, it was possible to increase the property's food independence by reducing food purchases from third parties.

There was a reduction in costs per arroba produced with the own food production at Angico farm.

With proper planting and management techniques, it was possible to overcome production barriers, such as adverse weather, pest attacks, diseases and wild animals, thus improving the enterprise's competitiveness.

There was the recovery of pasture areas degraded by the implementation of agriculture on plots destined to the production of feed for cattle confinement.

\section{References}

BARIONI, L. G.; TEDESCHI, L. O.; MARTHA JÚNIOR, G. B.; PAZZANESE, D.; VELOSO, R. F. Formulação de dietas de custo mínimo da matéria seca para bovinos de corte em planilha eletrônica. Planaltina, DF: Embrapa Cerrados, 2003. 7 p. (Embrapa Cerrados. Comunicado Técnico, 98).

BARROS, J. F. C.; CALADO, J. G. A cultura do milho. Portugal: Universidade de Évora, 2014. 52p.

BRASIL. Ministério da Agricultura, Pecuária e Abastecimento. Projeções do agronegócio: Brasil 2017/18 a 2027/28 - projeções de longo. Brasília: MAPA/ACE, 2018. 112 p.

BRASIL. Ministério da Agricultura, Pecuária e Abastecimento. Giro do boi - Projeções do Agronegócio - Brasil 2017/18 a 2027/2028: Carnes, $2018 . \quad$ Disponível em: https://www.beefpoint.com.br/projecoes-doagronegocio-brasil-2017-18-a-2027-2028-carnes/ . Acesso em: 20 fev. 2019.

BRASIL. Ministério da Agricultura, Pecuária e Abastecimento. Serviço de Inspeção Federal (SIF), 2016. Disponível em: https://www.gov.br/agricultura/ptbr/assuntos/inspecao/produtos-animal/sif/servicode-inspecao-federal-sif

. Acesso em: 30 out. 2020. 
BUSO, W. H. D.; MORGADO, H. S.; BORGES E SILVA, L.; FRANÇA, A. F. S. Utilização do sorgo forrageiro na alimentação animal. PUBVET, Londrina, v. 5, n.23, ed.170, art.1145, 2011. https://doi.org/10.22256/pubvet.v5n23.1145

CARDOSO, E. G. Engorda de bovinos em confinamento. Campo Grande: EMBRAPA, 1996.

CARVALHO, T.B.; ZEN S. A cadeia de pecuária de corte no Brasil: evolução e tendências. Revista Ipecege, Piracicaba, p. 12, 2017.

CONAB . Acompanhamento da safra brasileira: grãos. 2020. Disponível em: https://www.conab.gov.br/info-agro/safras. Acesso em: 01 set. 2020.

CONAB. Preços Agropecuários. 2019. Disponível em: https://www.conab.gov.br. Acesso em: $20 \mathrm{fev}$. 2019.

EMBRAPA SOJA. Soja em números (safra 2017 / 2018). Disponível em: <>. Acesso em: 01 nov. 2018.

GIL, A. C. Métodos e técnicas de pesquisa social. 6. ed. - São Paulo : Atlas, 2008.

GRUPO EMA. Empresa Marinho de Agropecuária do Pantanal Ltda. 2019. Disponível em: http://www.emapantanal.com.br. Acesso em: 20 maio 2019.

MANDARINO; R. A.; BARBOSAS; F. A.; CABRAL FILHO, L. S.; LOBO; C. F.; SILVAR, I. S.; OLIVEIRA, V.; DIOGOR, J. M. S.; GUIMARÃES JÚNIOR, R.

Desempenho produtivo e econômico do confinamento de bovinos zebuínos alimentados com três dietas de alto concentrado. Arquivo Brasileiro de Medicina Veterinária e Zootecnia, v.65, n.5, p.1463-1471, 2013. https://doi.org/10.1590/S0102-

$\underline{09352013000500027}$

MELLO, R.; RESENDE, F. D.; QUEIROZ, A. C.; FARIA, M. H.; OLIVEIRA, A. S.; SIQUEIRA, G. R. MELLO, RENIUS. Bio-economicity of the finishing phase on feedlot of crossbred young bulls slaughtered at different body weights. Revista Brasileira de Zootecnia, v.38, n.1, p.109-121, 2009. https://doi.org/10.1590/S1516-

$\underline{35982009000100015}$

MISSÃO, M. R. Soja: origem, classificação, utilização e uma visão abrangente do mercado. Maringá
Management: Revista de Ciências Empresariais, v. 3, n.1, p.8-10, 2006.

NEUMAN, W.L. Social Research Methods Qualitative and Quantitative Approaches. 3rd Edition, Allyn and Bacon, Boston, 1997.

PERIPOLLI, E.; OLIVEIRA, M. A. L.; BALDI, F.; PEREIRA, A. S. C.; VERCESI, A. E.; ALBUQUERQUE, L. G. Valores econômicos para sistemas de recria e engorda de bovinos Nelore e cruzado. Archivos de Zootecnia, v. 65, n. 250, p. 145-154, 2016. https://doi.org/10.21071/az.v65i250.481

SAMAIA, R. A evolução da nutrição na pecuária e o poder da extrusão - contexto histórico. 2019. Disponível em: https://www.nutratta.com.br/aevolucao-da-nutricao-na-pecuaria-e-o-poder-daextrusao-materia-completa/

. Acesso em: 08 jan. 2019.

SAMAIA, R.; ANSELMO, R. O grande desafio dos pecuaristas. 2019. Disponível em: https://www.nutratta.com.br/qual-o-impacto-danutricao-na-producao-pecuaria/

. Acesso em: 08 jan. 2019.

SENAR - Serviço Nacional de Aprendizagem Rural. Bovinocultura: manejo e alimentação de bovinos de corte em confinamento / Serviço Nacional de Aprendizagem Rural. - Brasília: Senar, 2018. 56 p.

TRIVIÑOS, A. N. S. Introdução à pesquisa em ciências sociais: a pesquisa qualitativa em educação. São Paulo: Atlas, 1987. 